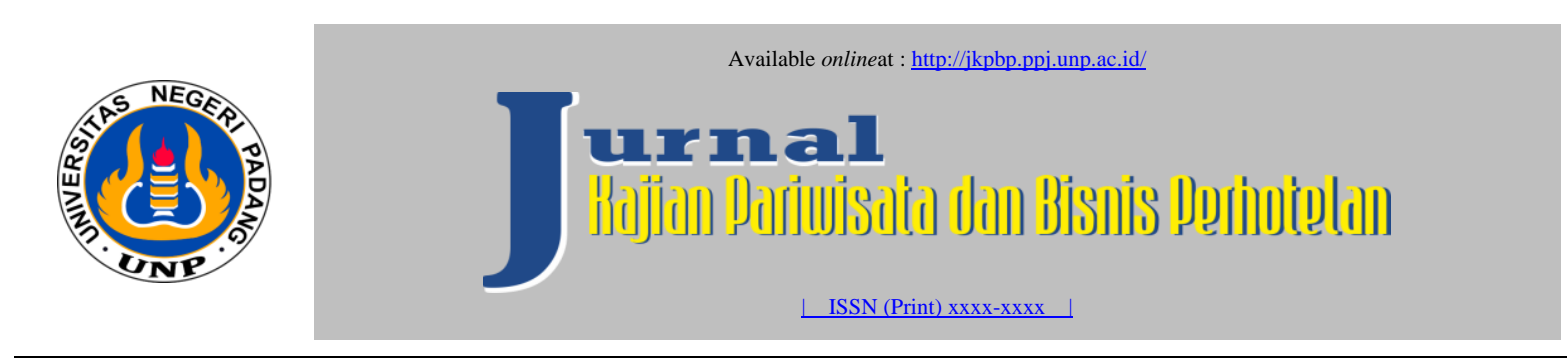

\title{
PENGARUH PROMOSI TERHADAP KEPUTUSAN BERKUNJUNG WISATAWAN KE OBJEK WISATA GREEN HOUSE LEZATTA KABUPATEN AGAM
}

\author{
Filma Sari' ${ }^{1}$, Hijriyantomi Suyuthie ${ }^{1}$ \\ ${ }^{1}$ Universitas Negeri Padang \\ ${ }^{2}$ Universitas Negeri Padang
}

Email: filmasarian@gmail.com, hsuyuthie@fpp.unp.ac.id

\begin{abstract}
ABSTRAK
Penelitian yang dilakukan bertujuan untuk menjelaskan dan mengetahui pengaruh promosi terhadap keputusan berkunjung wisatawan ke objek wisata Green House Lezatta. Penelitian ini tergolong kepada penelitian asosiatif kausal. Sampel diambil dari wisatawan yang berkunjung ke objek wisata Green House Lezatta. Sampel penelitian diambil menggunakan teknik purposive sampling, serta sampel berjumlah 98 orang responden. Data dikumpulkan dengan menyebarkan angket yang sudah disusun kemudian diberikan kepada responden yang telah diuji terlebih dahulu validitas serta reliabilitasnya. Dari hasil penelitian dapat disimpulkan: (1) Promosi berada pada golongan kurang setuju (53\%), (2) Keputusan berkunjung berada pada golongan setuju (49\%), (3) Hasil uji hipotesis regresi linear sederhana didapatkan F hitung 27.060 dengan signifikansi $0,00<0,05$ maka variabel promosi dapat menjelaskan keputusan berkunjung secara signifikan, Dan diperoleh $\mathrm{R}$ square senilai 0.220 yang artinya pengaruh variabel promosi terhadap variabel keputusan berkunjung adalah sebanyak $22 \%$ dan sisanya $78 \%$ faktor lain yang mempengaruhinya.
\end{abstract}

Kata Kunci: Promosi, Keputusan Berkunjung.

\section{PENDAHULUAN}

Industri pariwisata adalah satu dari industri yang berkembang dengan sangat cepat dewasa ini. Kegiatan pariwisata juga menjadi penyumbang devisa terbesar untuk negara pada saat ini. Berwisata bukan lagi sesuatu hal yang mewah bahkan berwisata pada saat sekarang ini sudah menjadi kebutuhan dan gaya hidup. Suatu objek wisata haruslah memiliki daya tarik khusus yang dapat menarik pengunjung untuk datang ke objek wisata tersebut [1].

Berkembangnya suatu objek wisata tak lepas dari keputusan berkunjung wisatawan ke objek wisata tersebut. Keputusan berkunjung merupakan salah satu tahapan dalam proses keputusan pembelian /berkunjung dimana konsumen benar-benar datang untuk membeli /berkunjung ke objek wisata tersebut [2]. Diperjelas lagi keputusan pembelian adalah sebuah pendekatan penyelesaian masalah yang dilakukan pada kegiatan manusia untuk membeli suatu barang atau jasa dalam memenuhi keinginan dan kebutuhan yang terdiri dari pengenalan kebutuhan dan keinginan, pencarian informasi, evaluasi terhadap alternatif pembelian, keputusan pembelian, dan tingkah laku setelah pembelian [4]. 
Proses keputusan pembelian konsumen terdiri dari beberapa indikator yaitu pengenalan kebutuhan, pencarian informasi, pengevaluasian alternatif, keputusan pembelian dan perilaku pasca pembelian [5]. Selanjutnya keputusan pembelian konsumen dipengaruhi oleh faktor-faktor yaitu : product, price, place, promotion, customer service [6].

Promosi merupakan salah satu faktor yang dapat mempengaruhi konsumen untuk melakukan pembelian atau datang berkunjung ke suatu objek wisata [3]. Promosi dapat diartikan suatu aktivitas, kegiatan atau usaha dalam rangka memberi informasi dan memberi pengaruh orang lain untuk mengkonsumsi produk yang ditawarkan [7]. Promosi sejatinya adalah suatu elemen yang salah satunya dibutuhkan dalam pengembangan sebuah produk wisata[3]. Selanjutnya, indikator promosi adalah perpaduan iklan, promosi penjualan, hubungan masyarakat, penjualan personal, dan sarana pemasaran langsung [7].

Satu diantara daerah tujuan wisata di Sumatera Barat adalah objek wisata Green House Lezatta yang mengusung konsep agrowisata, terletak di Koto Hilalang Jalan Raya BukittinggiPayakumbuh KM 9,5. Kawasan Green House Lezatta ini pada awalnya bermula dari satu kawasan yang dijadikan sebagai destinasi pembibitan bunga anggrek. Kemudian dikembangkan sehingga membentuk sebuah rumah boneka serta tanaman yang merambat di dinding rumahnya. Namun seiring dengan berjalannya waktu dan ide kreatif dari owner Green House Lezatta, tempat ini disulap menjadi objek wisata populer dari semua kalangan usia. Green House Lezatta ini memiliki luas 5.600 meter. Ditempat ini terdapat berbagai jenis tanaman dan tempat-tempat unik untuk berfoto seperti rumah barbie, rumah rabbit, rumah terbalik dan banyak lagi. Sebelum masuk ke dalam objek wisata diharuskan membeli tiket untuk dewasa dan remaja Rp 15.000 serta untuk anak-anak (usia 1-7tahun) Rp 10.000

Berdasarkan hasil pra penelitian yang dilakukan sebelumnya peneliti menemukan bahwa wisatawan mengetahui objek wisata Green House Lezatta dari postingan orang lain di sosial media bukan dari media promosi objek wisata Green House Lezatta. Hal ini disebabkan belum adanya periklanan yang dilakukan oleh pihak pengelola. Peneliti juga menemukan wisatawan menyatakan promosi di media cetak, seperti spanduk dan brosur, maupun media elektronik belum tersebarluaskan kepada wisatawan maupun masyarakat.

Dapat dilihat juga dari permasalahan untuk keputusan berkunjung yakni pengevaluasian alternatif terhadap promosi yang beredar dibeberapa media wisatawan mengatakan promosi yang ada tidak informatif serta tidak menarik. Dari perilaku pembelian berdasarkan pra penelitian wisatawan menyatakan tidak melakukan rekomendasi kepada orang lain untuk berkunjung. Serta adanya wisatawan merasa tidak puas berkunjung ke objek wisata Green House Lezatta.

Urgensi dari penelitian ini yaitu dengan dilakukannya promosi yang lebih gencar lagi maka akan berdampak pada meningkatnya keputusan berkunjung wisatawan ke Green House Lezatta yang pastinya akan membawa dampak positif serta bermanfaat baik dalam bidang ekonomi, sosial, budaya serta kehidupan disekitar objek wisata, yang tentunya dapat membuka peluang usaha juga bagi warga setempat. Namun sebaliknya jika tidak diperhatikan maka jumlah kunjungan akan berkurang.

\section{METODE PENELITIAN}

Penelitian ini tergolong kepada penelitian asosiatif kausal. Populasi dalam penelitian yang dilakukan ini adalah semua wisatawan yang berkunjung ke objek wisata Green House Lezatta. Sampel penelitian diambil dengan metode purposive sampling yang artinya pengambilan sampel 
dengan pertimbangan tertentu. Selanjutnya kriteria pengambilan sampel minimal pernah berkunjung ke objek wisata Greeen House Lezatta satu kali dan berusia 17 tahun keatas dengan jumlah sampel 98 responden. Data dikumpulkan dengan menyebarkan angket yang sudah disusun kemudian diberikan kepada responden yang telah diuji terlebih dahulu validitas serta reliabilitasnya. Dengan pengujian hipotesis menggunakan analisis regeresi sederhana.

\section{HASIL PENELITIAN DAN PEMBAHASAN}

\section{Promosi}

Variabel promosi yang telah disusun atas 15 pernyataan dan telah teruji validitas serta reliabilitasnya kemudian angket/ kuesioner diberikan kepada 98 responden untuk diberikan jawaban terkait promosi di objek wisata Green House Lezatta. Berdasarkan hasil yang diperoleh dari penelitian terkait promosi di objek wisata Green House Lezatta sebagai berikut ini:

Tabel 1. Distribusi Frekuensi Promosi

\begin{tabular}{|c|c|c|c|}
\hline Kategori & Rentang Skor & Frekuensi & $\mathbf{\%}$ \\
\hline Sangat Baik & $\geq 60$ & 0 & 0 \\
\hline Baik & $50-<60$ & 45 & 46 \\
\hline Cukup & $\mathbf{4 0}-<\mathbf{5 0}$ & $\mathbf{5 2}$ & $\mathbf{5 3}$ \\
\hline kurang Baik & $30-<40$ & 1 & 1 \\
\hline Buruk & $<30$ & 0 & 0 \\
\hline \multicolumn{2}{|c|}{ Total } & 98 & 100 \\
\hline
\end{tabular}

Sumber : Data Primer, 2020 (Diolah)

Dari hasil distribusi frekuensi diatas persentase pada penelitian ini 53\% dengan kategori cukup serta berada pada rentang skor $40-<50$.

\section{Keputusan Berkunjung}

Variabel keputusan berkunjung yang telah disusun atas 17 pernyataan dan telah teruji validitas serta reliabilitasnya kemudian angket/ kuesioner diberikan kepada 98 responden untuk diberikan jawaban terkait keputusan berkunjung di objek wisata Green House Lezatta. Berdasarkan hasil yang diperoleh dari penelitian terkait keputusan berkunjung di objek wisata Green House Lezatta sebagai berikut :

Tabel 2. Distribusi Frekuensi Keputusan Berkunjung

\begin{tabular}{|c|c|c|c|}
\hline Kategori & Rentang Skor & f & \% \\
\hline Sangat Baik & $\geq 67,95$ & 1 & 1 \\
\hline Baik & $\mathbf{5 6 , 6 5}-<\mathbf{6 7 , 9 5}$ & $\mathbf{4 8}$ & $\mathbf{4 9}$ \\
\hline Cukup & $45,35-<56,65$ & 47 & 48 \\
\hline Kurang Baik & $34,05-<45,35$ & 2 & 2 \\
\hline Buruk & $\leq 34,05$ & 0 & 0 \\
\hline \multicolumn{2}{|c|}{ Total } & 98 & 100 \\
\hline
\end{tabular}

Sumber: Data Primer, 2020 (Diolah)

Dari hasil distribusi frekuensi diatas persentase pada penelitian ini $49 \%$ dengan kategori baik serta berada pada batas rata-rata interval 56,65 - <67,95. 


\section{Hasil Pengujian Hipotesis}

Didapatkan nilai $\mathrm{F}$ hitung 27.060 dengan nilai signifikansi $0.00<0.05$ dimana variabel promosi menjelaskan variabel keputusan berkunjung secara signifikan. Maka dapat ditarik kesimpulan bahwa variabel promosi mempengaruhi variabel keputusan berkunjung, dan Sedangkan koefisien regresi senilai 0.528 dengan taraf signifikan $0.00<0.05$ mengandung arti bahwa setiap peningkatan sebesar 1 satuan promosi akan meningkatkan 0.528 satuan keputusan berkunjung. Nilai R Square 0,220 maka besaran kontribusi pengaruh promosi terhadap keputusan berkunjung sebanyak $22 \%$.

\section{Pembahasan}

\section{a. Promosi $(\mathrm{X})$}

Dilihat dari hasil penelitian tentang promosi di objek wisata Green House Lezatta, dapat diketahui bahwa dari 98 responden untuk promosi dengan persentasi 53\%. tergolong pada kategori cukup. Dengan demikian dapat diartikan bahwa mayoritas pengunjung cukup mengetahui tentang kegiatan-kegiatan promosi yang dilakukan oleh pihak pengelola Green House Lezatta.

\section{b. Keputusan Berkunjung (Y)}

Dilihat dari hasil penelitian tentang keputusan berkunjung di objek wisata Green House Lezatta dapat diketahui dari 98 responden keputusan berkunjung berada pada kategori baik, dengan persentase 49\%. Dapat disimpulkan bahwa pada objek wisata Green House Lezatta informasi dari promosi yang dilakukan dapat menarik wisatawan untuk berkunjung ke objek wisata. Dimana pencarian informasi merupakan salah satu tahapan dalam proses keputusan pembelian / berkunjung [9].

\section{c. Pengaruh Promosi Terhadap Keputusan Berkunjung}

Didapatkan nilai F hitung 27.060 dengan nilai signifikansi $0.00<0.05$ dimana variabel promosi menjelaskan variabel keputusan berkunjung secara signifikan. Sedangkan koefisien regresi senilai 0.528 dengan taraf signifikan $0.00<0.05$. Dan diperoleh nilai $R$ square sebesar 0.220 yang artinya bahwa pengaruh variabel promosi terhadap variabel keputusan berkunjung ialah sebanyak $22 \%$ dan sisanya $78 \%$ faktor lain yang mempengaruhi seperti factor lokasi, harga, kelompok acuan, pribadi dan lainnya.

Dari hasil penelitian terlihat bahwa promosi memiliki kontribusi yang cukup besar dalam mempengaruhi pengunjung untuk datang ke objek wisata Green House Lezatta, hal ini sesuai dengan beberapa teori yang dikemukakan sebelumnya dimana faktor promosi yang dilakukan oleh pemasar berperan cukup signifikan dalam menarik minat konsumen untuk dating ke suatu objek wisata.

\section{KESIMPULAN}

Dari data hasil penelitian dapat disimpulkan promosi di objek wisata secara keseluruhan berkategori kurang setuju serta nilai persentasi sebesar 53\%, dan keputusan berkunjung secara keseluruhan berkategori setuju dengan nilai persentasi sebesar 49\%.. Terdapat pengaruh yang signifikan antara promosi terhadap keputusan berkun jung, dengan kontribusi pengasruh sebesar $22 \%$, sedangkan $78 \%$ sisanya dipengaruhi oleh fasktor lain yang tidak diteliti dalam penelitian ini.

Dengan kontribusi pengaruh promosi yang cukup besar yaitu 22\%, maka diharapkan pihak pengelola dapat meningkatkan kegiatan-kegiatan promosi yang dilakukan. Serta juga menerapkan strategi-trategi promosi baru yang lebih efektif dalam meningkatkan kunjungan ke objek wisata Green House Lezatta. 


\section{DAFTAR PUSTAKA}

[1] T. Putra, "a Review on Penta Helix Actors in Village Tourism Development and Management," J. Bus. Hosp. Tour., vol. 5, no. 1, pp. 63-75, 2019, doi: 10.22334/jbhost.v5i1.150.

[2] Y. Abrian, A. Adrian, and R. Surendra, "Analysis of Factors Affecting Guest Decision in Purchase of Room Service in Hotel 'Grand Inna Padang,"” J. Bus. Hosp. Tour., vol. 5, no. 2, pp. 193-200, 2019, doi: 10.22334/jbhost.v5i2.165.

[3] F. Kamal, K. Kasmita, and Y. Abrian, "PENGARUH FAKTOR-FAKTOR PROMOSI TERHADAP KEPUTUSAN PEMBELIAN KAMAR TAMU DI HOTEL SAVALI

PADANG," J. Home Econ. Tour., vol. 15, no. 2, p. 43, 2017, doi: 10.1017/CBO9781107415324.004.

[4] Basu, Swasta dan Irawan. 2003. Manajemen Pemasaran Modern. Yogyakarta: Liberty Offset.

[5] Kotler, dan Amstrong. 2004. Prinsip-Prinsip Marketing, Edisi Ketujuh. Jakarta: Salemba Empat

[6] Assauri, Softjan. 2004. Manajemen Pemasaran. Jakarta: Rajawali Press.

[7] Kotler, Philip dan Amstrong, Gary. 2008. Prinsip-Prinsip Pemasaran, Edisi 12, Jilid 2. Jakarta: Erlangga

[8] Marpaung. 2016. Pengetahuan Kepariwisataan. Bandung: CV. Arfino

[9] Putri, WNA, Abrian, Youmil. 2018. Pengaruh Harga dan Lokasi Terhadap Keputusan Pembelian Kamar Di Grand Royal Denai Hotel Bukittinggi. http://ejournal.unp.ac.id 